\title{
Political Speaking in Art: Cultural Images of the Transforming Society
}

\author{
Dr. Fjoralba Satka
}

Aleksandër Moisiu University, Albania

Email: fjoralba_s@yahoo.com

\section{Doi:10.5901/ajis.2013.v2n11p160}

\begin{abstract}
This paper represents an examination in the field of visual art, in particular of painting, where political speaking has altered the traditional understanding and interpreting art images, their sociological context and the language of their messages. Political speaking in art is a challenge for artists to create models of cultural images of the Albanian transforming community, as well as it is a challenge for the audience to decode them. The focus of the paper is on the comparison between the politically speaking art of 'socialist realism' and understanding of its cultural images, and how the democratic changes in the state conceptualized the visual representation of the politically speaking contemporary painting. Political speaking in art is not only a special artistic feature, but it has functions to educate and cultivate, and to accustom to thought. Political speaking in the art of 'socialist realism' was used by the policy as a tool for premeditated ideological persuasion. It created a model of art that disseminated its influence through all socialist countries. Contemporary politically speaking Albanian art not only delivers rational agonistic modelsof art that use the public space for dethroning the same glorified communist policy, but has wider functions.
\end{abstract}

Keywords: Albanian art, political speaking in art, images, visual representation of a political idea, politically speaking art and its sociological context, coding and decoding political messages.

\section{Introduction}

This paper is concerned with the analysis of political speaking in visual art, in particular in painting, from the perspective of Albanian art development before and after the transition (1990). The II World War was named in Albania National War of Liberation/Guerilla War of the communist party. After 1944, there followed a virtual outburst of artistic representations of the war in commemorative annual exhibitions and rituals on the occasion of Albanian public or party holidays. From 1950 onwards, the new method of 'socialist realism' brought into use a symbolic notation and topics to express the political ideas of the communist power. This symbolic system was accommodated to the circumstances in the country and Enver Hoxha's dictatorship (1944-1985) who built a second 'iron curtain' round the country (Satka, 2011a).

The political speaking in Albanian visual art of 'socialist realism' (1944-1990) had two general topics, war and socialist construction.

From contemporary point of view, it is an area of confusion and controversy. Firstly, the relation of the art image of war to the history itself shows deflections of the facts. Secondly, the question of Albanian history, and especially the differences between history and memories, has come under discussion recently. Gjeçovi (2009), an Albanian authors underline the value of war as a sacred stage of the national history where the plan of Germany and Italy to split the country was successfully executed. Others emphasize the importance of memory when a political group proclaimed itself as an 'owner of the truth', and according to its regime the 'class struggle' and the 'dictatorship of the proletariat' symbolized the essence of the historical process. Actually, that part of history was full of massacre, deporting, internment, exile, imprisonments of thousands of Albanians (Topalli, 2008). Therefore, the political speaking on the partisan struggle of the party should be thought over instead of being remembered (Hamza, 2010).

Thirdly, art represents the main idea of the socialist construction of the country and society as glorious and victorious. It similarly concerns the matter of political speaking on historical events. Albanian authors uphold the idea that memory as an object of censorship, design and transfers, requires intelligence because the tomorrow's history will depend on the quality of today's memory, as well as history requires analysis and critical discourse to be rewritten (Lubonja, 2007). Over the 45-year propaganda of a manipulated history, politically speaking official art built united and distorted collective memory in the service of one regime round the myths of its prosperity (Baze, 2010).

Political speaking itself causes fundamental change in a society's view of how things work in the world. During every transition $(1944,1990)$, it forms cultural images of the transforming Albanian society. Examining the relation of the 
political speaking in Albanian art to history and memory, this paper is based on Pier Nora's (1989) conceptions and Jay Winter's examination of their senses: 'history is memory seen through documents; and memory is history seen through affect, through feelings, through emotions.' (Kalaci, 2009). Those affects, feelings, emotions and thoughts shape two types of images, the official image of the prosperous socialist society, and the hidden one of the real man's drama.

In sum, critical vectors of this investigation focus on the political speaking in art in relation to historical and social events, and cultural images of the society as results. To distinguish a real event from the politically speaking propaganda art during communism is fundamentally significant. On the part of art, its historical mission is to evoke collective memory of the past events. On the part of man, the individual memories of those who were persecuted have historical values. Nowadays, we should not controvert heroism of common people in the Liberation War, as well as we have to consider the phenomenon 'politically speaking art' as a subject to criticism. Taking in mind national historical facts, I have based my investigation on the concepts of authors as Jay Winter (2006), Jeffrey K. Olickand Joyce Robbins (1998), Maurice Halbwachs (1992), etc., and on some Albanian authors as well.

The idea of the discourse here is that the political speaking in art generates different cultural images of the transforming Albanian society in the time of transitions. First object for shaping was memory of war which may be analyzed using core concepts on history, and in terms of some aspects of the development of the art. The aim of the analysis is to highlight the political speaking in art and its cultural interpretations after the two Albanian transitions (1944, 1990). This will be a classic example of the descriptive basis of cultural history; in particular of art history which functions is to describe not to prescribe.

\section{Politically Speaking Art of 'Socialist Realism' as an Instrument of Collective Image-Building}

Used as a tool for premeditated ideological persuasion, the political speaking in Albanian official art served ideological purposes through its messages. First of all, The II World War was represented as a Guerilla War, waged by the communists, and people bound by the party line. During 45 years of socialism/communism, it was moulded a collective ideological image of Albanian people with unified thinking in the service of the dictator Hoxha and his regime for building cult of his personality (Baze, 2010). It was the first standardized and politically orientated cultural image of the transforming society after 1944.

The essential Orwellian thesis of a totally controlled environment could be find out in Albania in the strongest form due to Enver Hoxha's iron dictatorship. He built new public space of art where artists' production and viewers' thoughts on art, war and history were controlled through the state political discourse (Satka, 2011b:250). Since the first steps of the new method of 'socialist realism' in Albania (roughly 1950 onwards), it had been accepted clearly that works of art could play an important role in the creation of the political reality in the country. Politically speaking art built the new cultural image of the new socialist man. This paper argues that creators and spectators' views were to a great extent manipulated. That will be proved as painting after the democratic changes will be considered in comparative perspective.

The underlying premise here is that the official art is generally a politically speaking one. Pictures clearly and unambiguously convey ideological messages and form perceptions, thoughts, notions, and working method. Depiction of war and its perception was, due to the party line, glorious, victorious and impressive struggle. Art was used to symbolize the symbiosis of artists and audiences with the party ideology. War became a 'live forever' topic to demonstrate the heroism of communists and of the Albanian people as a soldier.

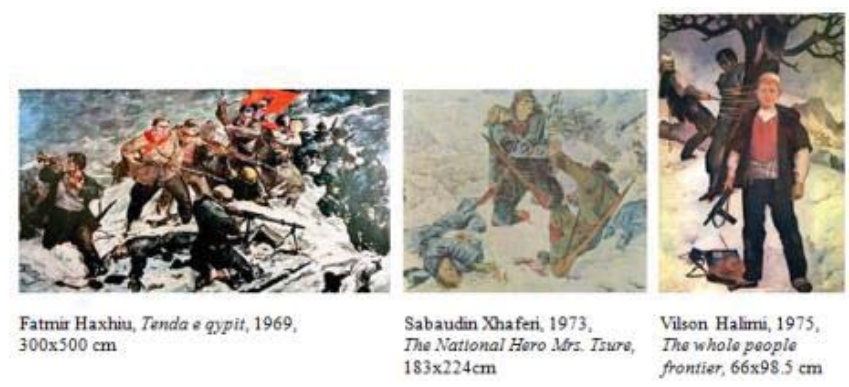

Paintings as Tenda e qypit (1969), The National Hero Mrs. Tsure (1973), The Whole People Frontier (1975), etc., elaborate the conception about association of men, women, and children with the party core idea 'life is war'. One of the 
functions of war depiction was for building political identity of the nation. The artistic messages became tantamount to historical speaking symbolizing the symbiosis between party line and people. Politically speaking official art influenced and contributed to the development of collective thinking united and homogeneous, and therefore limited and contestable understanding and interpretation of historyevents. So, the cultural image of Albanian people was clearly politically framed.

When the Albanian critics talked of 'socialist realism', they mainly referred to the political speaking of cognitive objects in art. Even in this case, artists had to do represent evidence in terms of the ruling conceptual form of 'live forever topic is the politics'. In one sense this may indeed be literal, i.e. the Guerilla War and socialist construction were the two substantial subjects exposed in every exhibition. In other sense, socialist construction was as a war (the Cold War) for predominance and victory, i.e. policy. In common sense terms, those pictures indicate the relationship between an artist and the motivating political conceptual system which was pictorially encoded and showed.

Paintings treating the national struggle must be looked not beyond the meanings of the objects themselves, but the simple symbols (pentacle, the Albanian red flag, the Red Party Book, rifles, the Albanian scarf) had to be interpreted in the right way relevant to the party ideology. In presentations of Partisan war firearms played extremely important role and a rifle became a symbol of national strength, unification, political glory, and readiness for war (Satka, 2012).

The problem now, over two decades after the transition and almost 70 years after the war, is whether the suggestions of the official socialist art, speaking in military uniform, should be treated, first, as a 'dead cultural image', intrinsic merely to the oldest generation, or second, they reverberate upon the memory of every Albanian today. In the first case, it means that they influenced upon the memory of small part of people who were possible eyewitnesses of that time, but do not today, so that the younger are not impressed. In the second case, the suggestions have built collective historical memory lasting and formed solid valuations. As my investigation over the image of war in Albanian painting and its role for memory of the Albanians shows, we can talk about a cultural image of the collective memory of the Albanian transforming society (Satka, 2013). Moreover, it is not 'dead'.

However, we have also to consider the question of contraposition and controverted facts conveying distorted or false information (Satka, 2011b). The general ideological role of art was a history-building means directing, suggesting and shaping a collective image of the socialist society unified.

In sum, works created under constraint are now perceived as expression of feeling of proud that pervades the Albanian painting, despite the dramatically shaped destiny of many in the time of the Cold War policy. Juxtaposed to the people `s heroism in the real war, the social theme in art was 'by-product' (Satka, 2011b) though. Politically speaking art was allowed to create defined images of political symbiosis, heroism, success, and glory.

There are undoubtedly definite truths in the pictorial versions of heroism, in spite of their propaganda functions. However, as a whole the political speaking in official painting of 'socialist realism' indicates a kind of rhetorical development of art due to the communist ideology. The general function of that approach was through political prescriptions to commit the historic civic sense to the socialist present. In sum, the political speaking in art of 'socialist realism' became a special artistic feature, and the understanding and interpretation on its cultural images had to educate and cultivate, and to accustom to 'right' thought.

\section{Artistic 'Evaluations' of the Political Speaking under Socialism}

Since the beginning of the 1990s, the modern Albanian consciousness has been seeking for a new approach. It is tempted to undermine the traditional socialist images and to dethrone their meanings. In the first years, time of massive upheavals, a lot of 'innocent' works were affected by the new political and aesthetical orientation. New political speaking appears in art and on it. The democratic changes in the state conceptualized the visual representation of

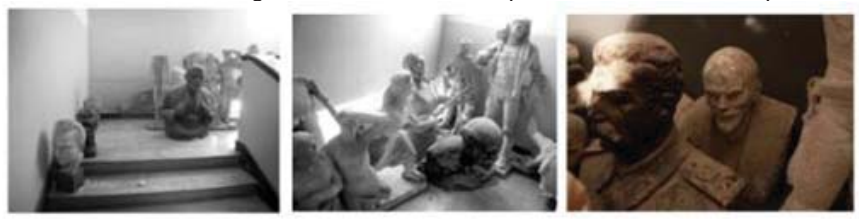

Heldi Pema. Leninism no more ${ }^{1}$. Photography the political speaking in contemporary painting.

${ }^{1}$ Heldi Pema. The Promenade Gallery. http://www.thepromenadegallery.org/artists/heldi-pema.html 
Heldi Pema, a photographer and artist, incidentally took pictures of the backstairs of the National Art Gallery in Tirana. It was heaped with statues of the nearest past, and Pema took pictures of them from different standpoints. The photographs represent a new perspective of political speaking in pictures. These twofold unadulterated visual records show: first, scrutiny to the political speaking in the socialist official sculpture; second, how the contemporary political speaking dethrone and undermine the policy of the nearest past.
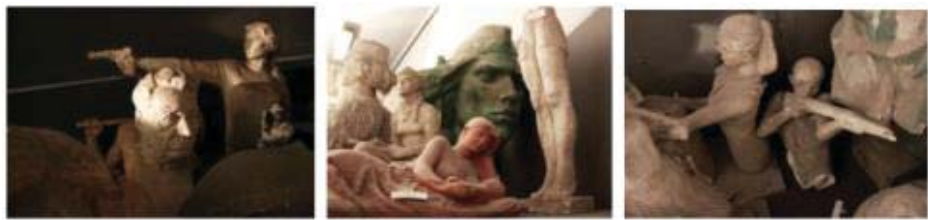

Heldi Pema. Leninism no more. Photography

Pema's collages on some of the photographs seek purposeful compositions to create abstract images which to convey critical attitude towards the political speaking in art. Under the mask of the collages, they reveal truths of the past, and impact as critical reassessment of the ruling communist ideology.
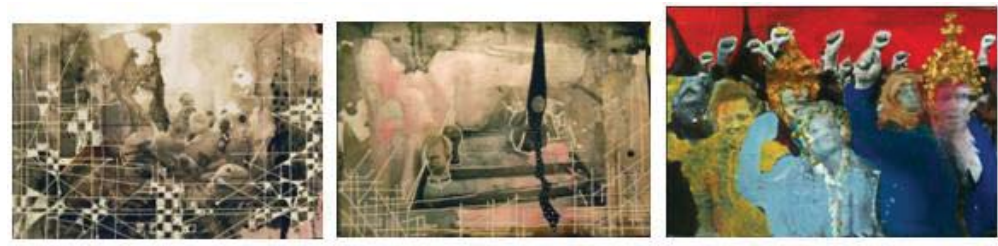

Heldi Pema. Leninism no more. Collages

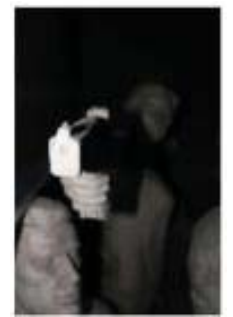

Heldi Pema. Interventions

Just one picture is named, Interventions. In the context of the entire collection it may be a title of a 'photo session' expressing the core idea of the time 'life is war' or the basic communist instrument 'political speaking as a ruling method of violence'.

Similar to the Albanian case is the situation in France during the World War II as indicative for actions of political power over the culture. Analyzing photographs of the destruction of Parisian public monuments that had been requisitioned by Nazi occupying forces for scrap metal, Kathryn Brown (2012) writes: 'Jahan'sphotographsof the metaphoric 'death' of these monuments are typically interpreted as a form of documentary realism.' In terms of the time, we can say that the' documentary realism' in art registers periods in the cultural history of recurring political actions regardless of the political system.

Apprehended as documentary realism, Pema's photographs and his collages are an original phenomenon of both the political speaking in art of 'socialist realism' and the modern attitude towards it in political terms. As a counterpoint to all acclaimed artists of 'socialist realism', dedicated to the policy, and evidenced by Pema's photographs, there were some who early anticipated the limits of the new direction of art development and saw the Albanian aspect of the soviet method in its true colors.

One of them is Maks Velo, a painter and writer, who after 10-year prison, because of his dissent from the 'socialist realism', worked in silence, out of the public space. He has expressed his collision with politics, and his views on art, in 
his books $(1995,2005,2010,2010 a)$ and in his works. Created in secret, torn and burnt by the political power, and later on recreated by Velo, his paintings had never been exposed until 1990. Such paintings of some Albanian artists form the parallel trend of Albanian painting, and because of their destiny called it 'painting in shadow' (Satka 2009, 2009 a).

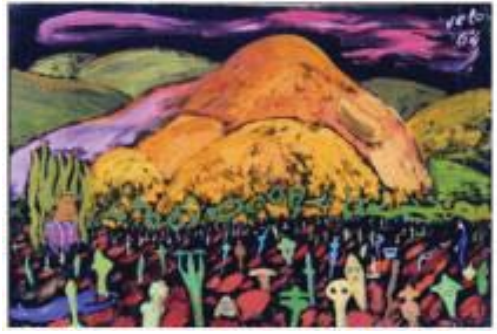

Maks Velo, Cemetery, 1964, tempera on paper

Velo resists, denies and undermines the canonical principles of 'socialist realism', as he himself is abstractionist. The pictures of the prison theme represent his deeply personal, extreme experiences on political speaking in art, protecting the political principles of 'socialist realism', as sheer insanity led to a crime against man. They are artistic assessment of the conflict between political rhetoric and political action.

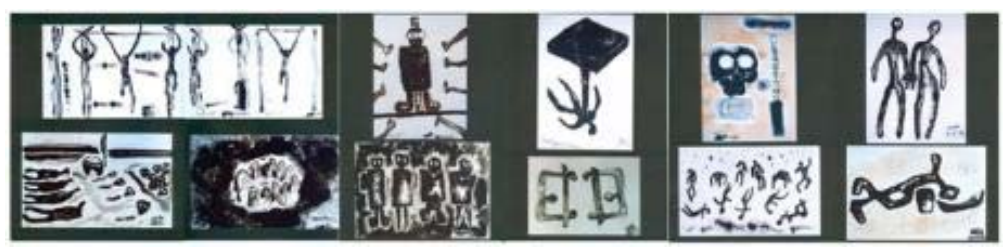

Maks Velo, The communist dictatorship. The investigation process and prison. 1991-1999

Quite the contraryto the widespread meanings of the political speaking in art of 'socialist realism' is the contemporary politically speaking painting. One of the younger artists after 1990 is Toni Milaqi, working in a conceptual manner imbued with the dramatic idea of the human suffering in 'silence'. Essentially, his pictures are expressive metaphors of criminal acts of the political power over the people. The artist (2009a) writes: 'The socialist realism period is one of the most extreme concerning the self-destroyed dynamic and impact upon the Albanian society.' The experiment of the communist doctrine and 'socialist realism', claims Milaqi, had as a result 'monsters in Albanian society formed' (2009j).

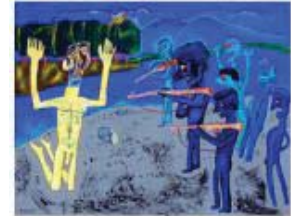

Toni Milaqi, Erecution II, 1996, Acrylic on canvas, $130 \times 100 \mathrm{~cm}$

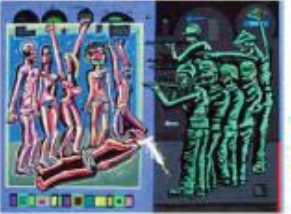

Toni Milaqi, Execution $I V, 2008$, acrylic on canvas, $120 \times 90$

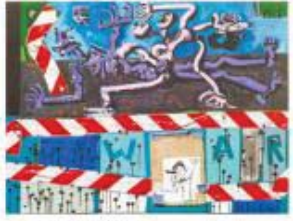

Toni Milaqi, Stop the War, 2003 cmmixed technique, $120 \times 90 \mathrm{~cm}$

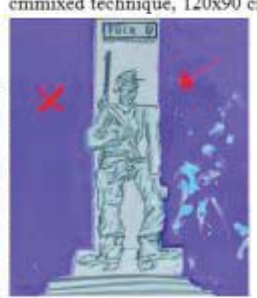

Toni Milagi, The Montument: Tale from the Part, acrylic on canvas. $80 \times 70 \mathrm{~cm}, 2012$

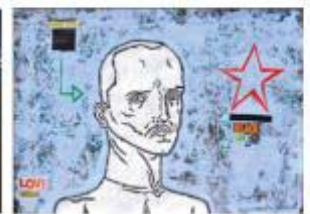

Toni Milaqi, Black, acrylic 11
Rialism and Military Expantion, 

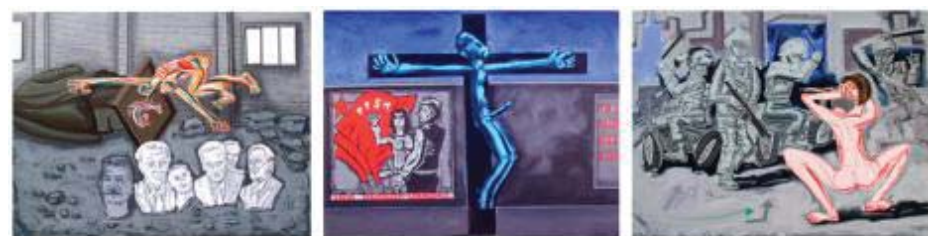

Toni Milaqi, The Dictators 'Ghost Acrylic on camvas, $120 \times 90 \mathrm{~cm}$
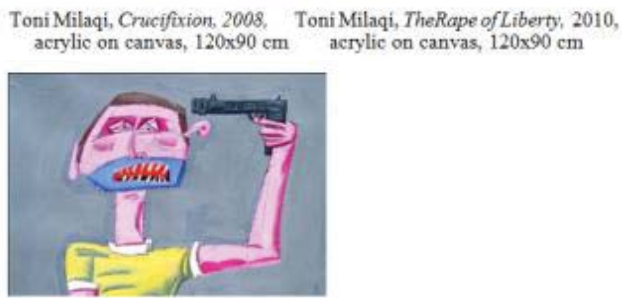

Toni Milaqi, To Be or Not to Be, detail 2011 , acrylic on paper, $70 \times 60 \mathrm{~cm}$

If we correlate Milaqi's paintings to Pema`s pictures, it is obvious that the political messages of both artists emphasize the destructive impact of political rhetoric irrespective of the political system. Pictures To be or not to be and Interventions just point to the two directions of destructive forces, to others and to ourselves. If we compare the painting before and after 1990, the ambivalent representations of political rhetoric of war as ideological pro-communist heroic images, on the one hand, and images of human suffering or resentment, on the other hand, are imbued with the clear idea of the political 'silence' in communism. Winter defines: 'Silenceis a space where nobody speaks what everybody knows, and it is an area which is socially regulated, socially constructed, socially preserved, and socially destroyed.' (Kalaci, 2009:34).

Albanian political silence occurred parallel to the political speaking and generated the phenomenon of 'unexpressed silence' in art. It manifested itself as 'painting in shadow' before 1990, and as politically speaking painting after the transition. As is evidenced by different works, their aspects are attacks, defend, shoot down, executions, human massacre, mind destruction, etc. Since the messages of this politically speaking art are life-important, Milaqi needs to make sure that has got across his messages to viewers. Therefore, he repeats and re-emphasizes them in multifold versions, so increasing the possibility that people are receiving and understanding the messages in the way intended. Through repetitions of the core idea in cognizable forms, the author argues that his conception is about the tragic consequences for people.

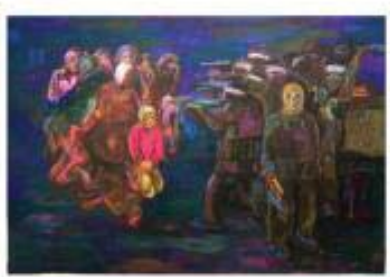

Alfred Dade, Execurion, oit, $250 \times 300 \mathrm{~cm}$ 1984

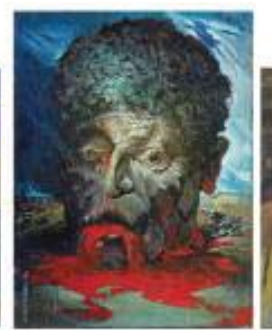

Artur Muharremi, Terror, $42 \times 32 \mathrm{~cm}$

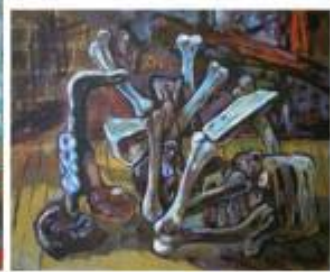

Alfred Dade, Massacre, oil, $80 \times 100 \mathrm{~cm}$

Politically speaking art makes tangible what people suffered behind the mask of the ostentatious and propaganda heroism in the official art of 'socialist realism'. It brings into prominence the cognition of that time, and shifts the focus away from the communist heroes and heroism to not less fundamentally significant idea of suffering, as a way of complementing the Albanian history through works of art. In Milaqi's Crucifixion we can recognize how even the Christian symbolic becomes an expression of a 'betrayed philosophy' (Milaqi, 2009a). For these reasons, expressed silence in 'painting in shadow' as well as in the politically speaking painting after 1990 may be comprehended as a counterpoint to the 'political silence' which Jay Winter considers. 


\section{Conclusion}

The stated aim in this text was to explore the political speaking in art works, thematically elaborating the aspects of war due to the 'socialist realism' requirements and individual artists' views. The more of the pictures, worked out during the period of socialist realism, pertain to the Albanian official art or to the illegal hidden 'painting in shadow'. Others have been created since 1990 to present.

Politically speaking socialist painting serviced to satisfy stated and implied ideological needs because of trust in the policy not to be lost. Because of that reason the political speaking itself was brought about by strict and consistent commitment to certain standards that achieve uniformity of art works in order to the specific 'socialist realism' requirements.

The general aspect is shown in terms of the 'socialist realism' and artists' relation to the Guerilla War. Parallel to it, the hidden painting unfolds ideas against the socialist policy and the new soviet method. This study provides clear evidence that ruling principle of the politically speaking art is the ancient one 'Cui prodest?' (to whom it is advantageous?, who stands to gain?). On the one hand, it is the socialist power; on the other hand, it works for the people's enlightenment. Either way, politically speaking art reveals cultural images of the Albanian society under socialism.

Another aspect refers to individual styles of politically speaking art presented by the newer generation of artists after the transition. The 'unexpressed silence' in socialism erupted subsequently as a post-factum speaking, from 1990 onward, about the suffocated individual memory. The pictorial expressions are manifestations of critical concepts of war either as political evil or national, cultural and personal destruction. These works of no compromise deliver visual material for reflection and revaluation of cultural images of the society before and after the transition.

Not less important aspect is the way in which authors are directing the viewer to reconsider the ideas of the represented in terms of the available memories and knowledge. The new points of view, re-embodying the 'unexpressed silence', refine Albanian painting from redundant heroism and pomposity, and emerge realistic aspects subsumed under what really happened in life in those years. In this way it is clarified the cultural image of the transforming Albanian society. One has to use knowledge and individual memory not only of what works represent, but what information they convey through years onward in comparison with specific aspects of their goals and circumstances of creation.

In conclusion, this paper is arguing that one work of politically speaking art should be compared with another in order to gain access to the relevant images of the society and the aspects of meaning as intended by the author. This process might take time, but the first step is the recognition that the common interpretation is somehow perverse without considering the specific political context of an art production as a whole, as well as the political context in representation of a war, in particular.

\section{References}

Brown, K. (2012). Remembering the Occupation: Pierre Jahan and Jean Cocteau. Abstract retrieved from www.qub.ac.uk/sites/.../Abstracts/Filetoupload,295146,en.docx

Gjeçovi, Xh. (2009). Lufta nuk duhet ngatërruar me diktaturën. // Gjecovi, Xh. (2009). War Should not Be Interfered with the Dictatorship, presented at the Conference on "Albania in World War II", Academy of Science, Tirana, Albania, 26 November. Retrieved from http://kulturashqiptare.blogspot.com/2009/11/xhelal-gjecovi-lufta-nuk-duhet.html

Halbwachs, M. (1992). On Collective Memory. Trans. anded. Lewis A. Coser, Chicago: University of Chicago Press.

Hamza, A. (2010, 26 Korrik). Politika partizane, ose krijimi i Universalizmit. // Agon HAMZA. (2010, 26 July). The Partisan Policy or Creating Universalism. Retrieved from http://forumi.shqiperia.com/threads/politika-partizane-ose-krijimi-i-universalizmit.24128/

Kalaci, S. (2009). Interview with Professor Jay Winter. Tarih1, 1, Boğaziçi University Department of History.

Lubonja, F. (2007, 22 shtator). Memorie dhe histori. Korrieri I/ Lubonja, F. ( 2007, September 22). Memory and History. Korrieri.

Milaqi, T. Blog. (2009, April 1). Kryqëzimi. Retrieved from http://tonimilaqi.blogspot.com/search/label/Social

Milaqi, T. Blog. (2009, January 1). Nacionalizmi dhe arti shqiptar. Retrieved from http://tonimilaqi.blogspot.com/search/label/Anti-Militare

Nora, P. (1989). Between Memory and History: Les Lieux de Mémoire. Representations, 26, Spring, 7-25.

Olick, K. J. \& Robbins, J. (1998). Social Memory Studies: From "Collective Memory" to the Historical Sociology of Mnemonic Practices. Annual Review of Sociology, 24, 105-140.

Satka, F. (2009). Tendencies in Albanian painting - 1950-1980. (Doctoral dissertation). Sofia: National Academy of Arts.

Satka, F. (2009a). Painting in Shadow. Problems of Art. Sofia, 4, 46-55.

Satka, F. (2011). Albanian Alternative Artists vs. Official Art under Communism. Avatars of Intellectuals under Communism, History of Communism in Europe, II, Bucharest: Zeta Books, 73-94.

Satka, F. (2011a). AlbanianTotalitarianism: Art Images and Political Power in Painting. Firearms, presented at the International Conference "Guns and Identity in the Nineteenth and Twentieth Centuries", 5-6 May2011, University of Kent, Canterbury, UK. 
Satka, F. (2011b). Political Power and Ideas on Space and Place Embodied in Albanian Socialist Painting. Presented at the 1st Global Conference "Space and Place", Mansfield College, Oxford, United Kingdom, 14-16 September 2011, at the printer's.

Satka, F. (2012). The Albanian Armed Socialist Art. Problems of Art, art studies quarterly, 1, Sofia, 44-49.

Satka, F. (2013). The Image of War: Albanian Painting and Memory of War of the Albanians. (In print).

Topalli, J. (2008, 16 dhjetor). Një demokraci pa memorie është demokraci në vuajtje. Koha Jonë. // Topalli, J. (2008, December 16). A Democracy Without Memory is a Democracy in Trouble. Our Time.

Velo, M. (1995). Kokëqethja. M. Barleti, Tiranë. // Velo, M. (1995). Clipping head. Tirana: Marlin Barleti.

Velo, M. (2005). Kohë anti-shenjë, Tirana: Zenit. // Maks VELO. Time Anti-sign. Tirana: Zenit, 2005.

Velo, M. (2010). Spaci. Tirana: Shtepia botuese “55”. // Velo, M. (2010). Spac, Tirana: Publishing house „55”.

Velo, M. (2010a). Hetimi, Shtepia botuese "55", Tiranë. // Velo, M. (2010). Investigation. Tirana: Publishing house „55”.

Winter, J. (2006). Remembering War: The Great War Between Memory and History in the Twentieth Century New Haven, CT: Yale University Press. 